\title{
The long-term effects of the biolicit procedure for original and biosimilar GCSF and EPO products in Hungary
}

\author{
LAJOS HORNYÁK ${ }^{1,2}$, ZSOLT NAGY ${ }^{1}$, ÁGNES VATHY FOGARASSYNÉ ${ }^{3}$, DÓRA ENDREI ${ }^{1}$, \\ TÍMEA CSÁKVÁRI ${ }^{1}$, BALÁZS RÉPÁSY ${ }^{1}$, SÁRA KRESZ ${ }^{1}$, IMRE BONCZ ${ }^{1}$ \\ ${ }^{1}$ Institute for Health Insurance, University of Pécs, Mária utca 5-7, 7621 Pécs, Hungary \\ ${ }^{2}$ Oncology Department, Csolnoky Ferenc Hospital of County Veszprém, Kórház utca 1, 8200 Veszprém, Hungary \\ ${ }^{3}$ Faculty of Information and Technology, Egyetem utca 10, 8200 Veszprém, Hungary \\ * Corresponding author: Lajos Hornyák \\ E-mail:lajos.hornyak@gmail.com
}

Received: 26 January 2021 / Revised: 30 March 2021 / Accepted: 2 April 2021

\begin{abstract}
Aim: In the present study, we aimed to analyse the long-term effects of the biosimilar bids of the Hungarian National Health Insurance Fund Administration (NEAK) regarding the colony stimulating factor (GCSF) and erythropoietin (EPO) drugs.

Data and Methods: Our analysis is based on the data derived from the nationwide pharma-ceutical database of the Hungarian National Health Insurance Fund Administration. The days of treatment (DOT) and reimbursement figures of 12 months periods has been compared. These periods were the single 12 months period before (01.07.2011-30.06.2012.), the double 12 months period immediately after (01.07.2012.-30.06.2013. and 01.07.2013.-30.06.2014.) and the double 12 months periods 5 years after (01.07.2017.-30.06.2018. and 01.07.2018.-30.06.2019.) the first biosimilar bid performed in March 2012 in Hungary.

Results: In the 12 months preceding the price competition bid of biosimilar products 13974 patients received G-CSF and 7.49 billion HUF health insurance reimbursement has been paid. During the investigated double 12 months period 5 years later the turnover of the product increased (314760 and 340100 DOT value), whereas the reimbursement decreased (2.03 billion HUF, and 1.95 billion HUF respectively). During the year before the price competi-tion bid of biosimilar products the treatment of 4167 patients with erythropoietin incurred reimbursement of 2.33 billion HUF. In the last 2 years of the study the turnovers were 48727 and 50813 DOT values with decreased reimbursement (1.004 billion HUF and 1.002 billion HUF respectively).

Conclusions: The long-term analyses of the Hungarian price competition bid of biosimilar products revealed that in case of colonystimulating factor products the health insurance re-imbursement decreased despite the elevated turnover in a longer period as well. During the years following the start of the price competition bid the swift from original products to bio-similars could be observed.
\end{abstract}

Keywords: biosimilar, price competition, reimbursement, bid, drug market, access.

\section{Introduction}

The advent of biological drugs has created a new situation both in production and application of these new drugs but also in drug reimbursement by health insurance organizations. Initially, it was of utmost importance to prioritise the concept of biological or biosimilar drugs. [1] The introduction of biosimilar products to the drug market made it possible to choose from multiple available drugs thus generating a price competition which inevitably means a significant decrease in source outflow for the social security authorities [2,26-29].

The European Medicines Agency promoted the use of these products by defining procedures for their use in the directives issued in 2011. Hungary was one of the first countries where the legal back- ground was provided [Regulation 52/2005. (XI. 18.) of the Hungarian Health Ministry].

Due to a considerable rise in the cost of treatments the Hungarian National Health Insurance Fund Administration (NHIFA/OEP) introduced the biobid procedure at the beginning of 2012.

The financial outcomes of the first couple of years fully supported the existence of this procedure. A smooth switch from the more expensive original products to biosimilars yielding decreased overall budget spent on reimbursement could be observed. In a previous publication we reported on the biobid procedure $[2,5]$.

In case of every decree its long-term effects on the targeted market should be considered. It is especially valid for the biosimilar drugs introduced to the drug market after expiry of patent for the 
original biological drugs, since the number of approved biosimilar drugs is continuously increasing. Although, 14 biosimilar products were approved in the EU by the autumn of 2013 [3] by July 2020 this number was increased to 58 [4].

On March 1 in each year, based on the decree 32/2004 ESzCsM (Hungarian Ministry of Health, Social and Family Affairs), the NEAK (previously OEP) started an official procedure in the regarded groups of drugs. In January 2012 the bid process for 3 therapeutic groups of drugs (colony stimulating factors, erythropoietin and growth hormones /somotropin/ ) was to be announced, but the final announcement covered only the first two groups. As it has been discussed above, NEAK repeats the process annually.

The Hungarian healthcare authorities launched the biobid process among the first countries in 2012.
In the present study, we aimed to analyse the long-range effects of the biosimilar bids of the Hungarian National Health Insurance Fund-Administration (NEAK/OEP) regarding the colony stimulating factor (GCSF) and erythropoietin (EPO) drugs. Our study covered the single 12 months period before, the double 12 months period immediately after as well as the double 12 months periods 5 years after the first biosimilar bid.

\section{Data and methods}

\subsection{Regulatory Environment}

The molecules marketed after the expiration of the original biological drugs allow the Health Insurance Fund to reduce the costs whilst still pro-

Table I Products Obtained Preferred Status from Social Security Authorities for a Biobid Year from 01.07.2011., and from 07.07. 2017.

\begin{tabular}{|c|c|c|c|c|c|}
\hline $\begin{array}{c}\text { Active } \\
\text { Substance }\end{array}$ & Brand Name & Packaging & $\begin{array}{c}\text { Consumer } \\
\text { Price } \\
\text { 30.06.2012. }\end{array}$ & $\begin{array}{c}\text { Consumer } \\
\text { Price } \\
\text { 01.07.2012. }\end{array}$ & $\begin{array}{c}\text { Consumer } \\
\text { Price } \\
\text { 01.07.2017. }\end{array}$ \\
\hline \multirow{10}{*}{ filgrastim } & ACCOFIL $48 \mathrm{M} / 0,5 \mathrm{ML}$ & $5 \mathrm{x} 0.5 \mathrm{ml}$ & - & - & 37255 \\
\hline & ACCOFIL $30 \mathrm{M} / 0,5 \mathrm{ML}$ & $5 \times 0.5 \mathrm{ml}$ & - & - & 23313 \\
\hline & NIVESTIM $48 \mathrm{M} / 0,5 \mathrm{ML}$ & $5 \times 0.5 \mathrm{ml}$ & 83452 & 74370 & 40942 \\
\hline & NIVESTIM $30 \mathrm{M} / 0,5 \mathrm{ML}$ & $5 \times 0.5 \mathrm{ml}$ & 52183 & 46541 & 25600 \\
\hline & ZARZIO $48 \mathrm{M} / 0,5 \mathrm{ML}$ & $5 \times 0.5 \mathrm{ml}$ & 83453 & 75183 & 38129 \\
\hline & ZARZIO $30 \mathrm{M} / 0,5 \mathrm{ML}$ & $5 \times 0.5 \mathrm{ml}$ & 52184 & 47013 & 23831 \\
\hline & RATIOGRASTIM $48 \mathrm{M} / 0,5 \mathrm{ML}$ & $5 \times 0.8 \mathrm{ml}$ & 102819 & 82478 & 37877 \\
\hline & RATIOGRASTIM $30 \mathrm{M} / 0,5 \mathrm{ML}$ & $5 \times 0.5 \mathrm{ml}$ & 64260 & 51608 & 23674 \\
\hline & TEVAGRASTIM $48 \mathrm{M} / 0,5 \mathrm{ML}$ & $5 \times 0.8 \mathrm{ml}$ & 92627 & 92627 & - \\
\hline & TEVAGRASTIM $30 \mathrm{M} / 0,5 \mathrm{ML}$ & $5 \times 0.5 \mathrm{ml}$ & 57925 & 57925 & - \\
\hline \multirow{14}{*}{ eritropoietin } & EPORATIO 10000 NE/1 ML & $6 \times 1 \mathrm{ml}$ & 116655 & 116655 & - \\
\hline & EPORATIO $20000 \mathrm{NE} / 1 \mathrm{ML}$ & $4 \times 1 \mathrm{ml}$ & 155243 & 155243 & 117179 \\
\hline & EPORATIO $30000 \mathrm{NE} / 1 \mathrm{ML}$ & $4 \mathrm{x} 1 \mathrm{ml}$ & 232418 & 232418 & 175768 \\
\hline & RETACRIT $10000 \mathrm{NE} / 1,0 \mathrm{ML}$ & $1 \mathrm{x} 1 \mathrm{ml}$ & 20186 & 13260 & - \\
\hline & RETACRIT $10000 \mathrm{NE} / 1,0 \mathrm{ML}$ & $6 \times 1 \mathrm{ml}$ & 116655 & 77556 & - \\
\hline & RETACRIT $20000 \mathrm{NE} / 0,5 \mathrm{ML}$ & $1 \mathrm{x} 0,5 \mathrm{ml}$ & 39480 & 26114 & - \\
\hline & RETACRIT $30000 \mathrm{NE} / 0,75 \mathrm{ML}$ & $1 \mathrm{x} 0.75 \mathrm{ml}$ & 58774 & 38972 & - \\
\hline & RETACRIT $30000 \mathrm{NE} / 0,75 \mathrm{ML}$ & $4 \times 0.75 \mathrm{ml}$ & - & - & 118149 \\
\hline & RETACRIT $40000 \mathrm{NE} / 1,0 \mathrm{ML}$ & $1 \mathrm{x} 1 \mathrm{ml}$ & 78068 & 52002 & - \\
\hline & RETACRIT $40000 \mathrm{NE} / 1,0 \mathrm{ML}$ & $4 \mathrm{x} 1 \mathrm{ml}$ & - & - & 147448 \\
\hline & BINOCRIT $10000 \mathrm{NE} / 1,0 \mathrm{ML}$ & $6 \times 1.0 \mathrm{ml}$ & 94506 & 81347 & - \\
\hline & BINOCRIT $30000 \mathrm{NE} / 1,0 \mathrm{ML}$ & $1 \mathrm{x} 0.75 \mathrm{ml}$ & - & - & 29283 \\
\hline & BINOCRIT $40000 \mathrm{NE} / 1,0 \mathrm{ML}$ & $1 \times 1.0 \mathrm{ml}$ & 70239 & 54231 & 39043 \\
\hline & BINOCRIT $40000 \mathrm{NE} / 1,0 \mathrm{ML}$ & $4 \times 1.0 \mathrm{ml}$ & - & - & 156176 \\
\hline
\end{tabular}


Table II Health insurance reimbursement between 01.07.2011.-30.06.2012. $\left.\left(^{*}\right), 01.07 .2017 .-30.06 .2018 . .^{* *}\right)$ and 01.07.2018.-30.06.2019. (***)

\begin{tabular}{l|c|c|c}
\hline \multirow{2}{*}{} & \multicolumn{2}{|c}{ Health insurance reimbursement (in billion HUF) } \\
\cline { 2 - 4 } & $\begin{array}{c}\mathbf{1 2} \text { months before } \\
\text { biosimilar bid } \\
\text { (m HUF)* }\end{array}$ & $\begin{array}{c}\text { Sixth 12 months after } \\
\text { biosimilar bid } \\
\text { (m HUF)** }\end{array}$ & $\begin{array}{c}\text { Seventh 12 months after } \\
\text { biosimilar bid } \\
\text { (m HUF)*** }\end{array}$ \\
\hline G-CSF & 7488 & 2039 & 1955 \\
\hline EPO & 2336 & 928 & 943 \\
\hline Total reimbursement & 9824 & 2967 & 2898 \\
\hline Changes (- m HUF) & - & -6857 & -6926 \\
\hline Changes (- \%) & - & $-69.7 \%$ & $-70.5 \%$ \\
\hline
\end{tabular}

viding the required level of insurance for the patients. [6-12]. It is not by chance that the cost containment measures so successfully utilized by generic drugs (drug bids at every three or six months) cannot be followed here.

Being cautious is of paramount importance since these products are proteins. Although, they are interchangeable by their therapeutic efficiency, but different protein based active agents possess different levels of human immunogenicity therefore, their frequent switch at a given patient is not recommended due to the elevated level of antibody formation. [cf. corresponding regulations].

Based on the regulations introduced in Hungary in 2012 the specification of the bidding process valid for the given biobid year (from July 1 of the given year till June 30 of the following year) is announced at the beginning of each calendar year. The social security authorities selected the preferred drugs for a period of 12 moths based on the lowest price. This helps the patients and their doctors to reduce the immunogenicity risks connected with biological drugs by avoiding a possible series of drug-switch in their therapy. All of this provides the pharmaceutical companies with reliable market conditions for a whole year and later deriving from their previous achievements and data a predictable market share. It can also improve the sustainability of medical care.

Based on the results of the price-bid, the drugs with the lowest bid and other drugs with a bid not exceeding the lowest one by more than $10 \%$ were awarded the status of a preferred biological drug. The health insurance reimbursement of such drugs is $100 \%$, and the co-payment paid by the patients is no less than 300 Hungarian Forint (HUF). The drugs falling in the price range that was higher by $10-30 \%$ than the lowest bid also received reimbursement from the social security system with a minimum and maximum co-payment from the patients of 1500 and 3500 HUF, respectively.
The prices determined on the basis of the pricebid process were valid for a year, between July $1^{\text {st }}$ of the given year and June 30 of the following year. The regulation also required that the percentage of the preferred drugs calculated in days on treatment (DOT) in a cycle should be $40 \%$ during the first year and $70 \%$ during the subsequent years [13].

The structure of the Hungarian Healthcare System [14-16] and its financing characteristics [1721,] are described in detail elsewhere.

\subsection{Analysis methodology of the bio-bid process}

The data used in this analysis was derived from the financing database of National Health Insurance Fund of Hungary (NEAK previously OEP), and they covered the interval between July 1, 2011 and June 30, 2014 as well as July 1, 2017 and Jun 1, 2019. The present analysis covers the general characteristics of payoff in the drug reimbursement (outpatient, receipt based) budget.

The current study was also retrospective, and it aimed to analyse the public drug utilization data published monthly on the web page of NEAK, including summary data at the end of the year (December 31st). The results of our previously published study have been incorporated. The aim of this study was not to provide a detailed specialty (adult or paediatric haematology and oncology) and disease-type related (ICD based prescription indication) analysis. The present analysis also does not investigate the incidental geographical differences in payoff in the drug reimbursement budget.

The change in the number of patients treated with the above-mentioned group of drugs and the related financial consequences during the period of 2017-2019 compared to the period of 2012-2014 was studied. The later period has already been studied in one of our previous publication. The change in unit selling of pharmacy utilization and 
Table 3 Days of treatment (DOT) 01.07.2011.-30.06.2012. $\left(^{*}\right), 01.07 .2017 .-06.30 .2018 .\left(^{* *}\right)$ and 01.07.2018.-30.06.2019. $\left(^{* * *}\right)$

\begin{tabular}{|c|c|c|c|}
\hline & $\begin{array}{l}12 \text { months } \\
\text { before } \\
\text { biosimilar } \\
\text { bid * }\end{array}$ & $\begin{array}{c}\text { Sixth } 12 \\
\text { months after } \\
\text { biosimilar } \\
\text { bid } * *\end{array}$ & $\begin{array}{c}\text { Seventh } 12 \\
\text { months after } \\
\text { biosimilar bid } \\
* * *\end{array}$ \\
\hline G-CSF Health insurance reimbursement DOT & 198010 & 314760 & 340100 \\
\hline $\begin{array}{l}\text { The Change in Total Number of Days in Therapy Subsidized } \\
\text { by Social Security Authorities Relative to the Period Before } \\
\text { the Bio Bid }\end{array}$ & - & 116750 & 142090 \\
\hline Changes (\%) & - & $59 \%$ & $72 \%$ \\
\hline EPO Health insurance reimbursement DOT & 101983 & 48727 & 50813 \\
\hline $\begin{array}{l}\text { The Change in Total Number of Days in Therapy Subsidized } \\
\text { by Social Security Authorities Relative to the Period Before } \\
\text { the Bio Bid }\end{array}$ & - & -53256 & -51170 \\
\hline Changes (\%) & - & $-52 \%$ & $-50 \%$ \\
\hline
\end{tabular}

the accompanying social security reimbursement outflow has also been analysed for both of the 12 months periods (July 01, 2017 - June 30, 2018 and July 01, 2018 - June 30, 2019) following the two consecutive biobid processes in March 2017 and 2018. The unit selling figures were replaced by the days on treatment (DOT) values. The change associated with the drugs in the preferred price range was studied. The treatments subsidized by individual reimbursements were not studied.

\section{Results}

\subsection{The general findings of the bio-bidding procedure}

As a result of the first price bidding in the category of colony stimulating factors, two biosimilar drugs (Nivestim and Zarzio) were awarded the status of preferred drugs for the time interval between July 1, 2012 and June 30, 2013. One biosimilar drug (Ratiograstim) still received reimbursement status with a co-payment of 1500 HUF for the patients. One other biosimilar (Tevagrastim) and an original drug (Neupogen) lost its reimbursement starting November 1, 2012. Owing to the first price bidding in the category of erythropoietins, three biosimilar drugs (Binocrit, Eporatio, Retacrit) were awarded the status of preferred drugs for the time interval between $1^{\text {th }}$ July 1, 2012 and June 30, 2013. Whereas, all of the original drugs (Eprex, Neorecormon, Aranesp) lost their reimbursement. The original drugs losing their reimbursement remained available for the patients with ongoing therapy between July 1 and October 30 in 2012 for a 3500 HUF co-payment. Due to the second price bidding three biosimilar colony stimulating factor and three erythropoietin products (Nivestim, Zarzio, Ratiogastrim, and Binocrit, Ep- oratio, Retacrit) were available for the patients for a unified co-payment of $300 \mathrm{HUF} /$ unit. The original biological products with previous significant market share lost their market position. During the two biobid years of the second part of the investigation (July 1, 2017 - June 30, 2018 and July 1, 2018 - June 30, 2019) the products Accofil, Nivestim, Zarzio, Ratiograstim, and Retacrit, Binocrit, Eporatio were available with priority reimbursement.

The advantageous change in the number of patients and the budget spent on reimbursement was described in our previous publications. To the detriment of the expensive original products the biosimilar products with favourable price for both the health care payer and patients gained dominant market share. Regarding the timespan five years later, the data analysis of neither the erythropoietin nor the colony stimulating factor products revealed a significant change in the figures of pharmacy utilization, DOT or units sold. Compared to the first biobid year the decreased public expenditure on biological medicines remained constant in the long run.

\subsection{Trading of G-CSF drugs}

In case of G-CSF drugs during the 12 months prior to the bid process, 13974 patients received GCFS treatment with a reimbursement of 7.490 billion HUF. During the first and second year after the bid process, 13352 and 13185 patients received it, respectively. This shows a minimal decrease. In the year preceding the first bid the total amount of reimbursement amounted to 7.490 billion HUF. In the following two years the decreased overall budget spent on reimbursement decreased to 4.19 and 3.590 billion HUF, respectively. Later, during 
the two years studied the decreased overall budget spent on reimbursement further decreased to 2.039 and 1.955 billion HUF.

\subsection{Trading of Erythropoietin (EPO) drugs}

In case of EPO, during the 12 months prior to the bid process 4167 patients were treated with a reimbursement amounting to 2.33 billion HUF. During the following two years 3647 and 3794 patients received this treatment, involving a slight decrease in the numbers. Prior to the biobid process $17 \%$ of the patients under ESA treatment received biosimilar drugs whereas, in the following year this ratio was increased to $95 \%$. Five years after the first biobid process, during the two years studied DOT values of 48727 and 50813 were reported representing an increase compared to the annual number prior to the biobid process. During the year preceding the biobid the total amount of reimbursement paid out for these products amounted to 2.330 billion HUF. During the following two years the decreased overall budget spent on reimbursement decreased to 1.203 and 1.130 billion HUF, respectively. During the last two years studied the decreased overall budget spent on reimbursement was further reduced to 0.928 and 0.943 billion HUF.

\section{Discussion}

The potential benefit of biosimilars in improving patient access to biological therapies were described in previous studies [27,29]. The research study carried out by Harsányi et al. could not confirm the assumption that the advent of biosimilar products enhanced the availability of the biological therapies for the patients [26].

Kaló et al. described the two conflicting factors influencing the cost-saving potential of off-patent pharmaceutcials, namely price erosion and drug utilisation, therefore, we also included the DOT based evaluation in our study [28].

For G-CSF, it can be concluded that due to the biobid process a continuous decrease of decreased overall budget spent on reimbursement could be observed during these years.

For EPO, it can be concluded that due to the biobid process a slight decrease or stabilization in the decreased overall budget spent on reimbursement could be observed. In case of EPO, the decreased DOT values can be explained by the more and more frequently applied targeted oncological therapies and immunotherapies, and consequently significantly less frequent chemotherapy induced anaemia during the treatment of cancer patients.

The conditions of the development, manufacturing and marketing authorization for biosimilar drugs are more restrictive than for traditional generic drugs $[22,23]$.

As a result of the so-called biobid process in Hungary (operative since July 2012) regarding the financing of the GCSF biological group (colony stimulating factors, ATC L03AA02, L03AA013, L03AA14) and EPO (Erythropoietin, ATC B03XA01, B03XA02) products, the amount of money spent on subsidizing the price of drugs belonging these groups after the first two biobid years was reduced by 5.287 billion HUF (from 9.82 billion HUF to 4.533 billion HUF), and it reduced the social security subvention spent in this sector by $54 \%$. Meanwhile, the number of patients treated with these drugs only slightly decreased. However, later the pegfilgrastim biosimilars appeared on the market the regulations remained unchanged and they can be prescribed with priority reimbursement only in secondary prophylactic treatment.

Although the headway of the biological drugs compared to the small molecule drugs can be regarded as a reason for resulting in price surge of the biological drugs and the biosimilar drugs provide a great opportunity for cost cuts for the health care payers all over the world. The cost of biological drugs amounts to approximately 70 billion USD in the USA and 60 billion EUR in the EU $[24,25]$.

The regulation concerning the approval of biosimilar medicinal products has withstood the test of time. Internationally, a huge amount of knowledge is available about these drugs in the form of several millions of patient-days, and the results have proven that the biosimilar drugs are a safe and efficient alternative to the original biological therapies [30-33].

Overall, it can be concluded that in the Hungarian biobid process, the number of patients involved in the GCSF and EPO treatments is slightly decreased, while the expenditure spent by NEAK for reimbursing these drugs was considerably reduced during the consecutive biobid processes and years even on longer range.

It is worth considering performing a study about the extension of the biobid process to further groups of active substances as well. With re- 
spect to the safety of patients' pharmacovigilance and compliance is of utmost importance in this group of drugs. In January 2012 the bid process was planned for 3 therapeutic groups of drugs but finally the third group, the growth hormones were not involved in the process. During the last couple of recent years, the itemized financing has become a routine practice in the treatment of patients. As a consequence, independently from the direct financing route of hospitals patients can get access to the most uptodate biological treatments. In the group of these products by the appearance of biosimilars and possible registration of forthcoming biosimilar drugs the biobid process could be applied.

It can be concluded that the appearance of biosimilar drugs on the market and the subsequently introduced biobid process by the financing body induced a price competition resulting in a considerable and continuous decrease of decreased overall budget spent on reimbursement of NEAK independently from changes in drug utilization measured by the number of treatment days.

\section{Study limitations}

The NEAK database is continuously updated thus as new data sets are uploaded changes can be observed. To provide proper equivalence for the original and the various biosimilar products we switched to DOT values which was not possible due to technical difficulties in our previous study. In the study launched in 2012 we studied the original-biosimilar interchange in therapies thus DOTbased calculations did not seem preferable for us.

From 2012 on in oncological therapies in palliative care the classical chemotherapy was partially replaced by targeted and biological therapies. By applying these newer therapies the frequency of induced anaemia was considerably reduced, however, the impact of reduced agranulocytosis on the use of erythropoietin could not be directly measured.

The current study was supported by the grant of the Hungarian Government: „Thematic Ex-cellence Program 2020 -- National Excellence Subprogram („2020-4.1.1-TKP2020”)".

\section{References}

1. Buzás Zs.: A biológiai gyógyszerek besorolása és hatósági értékelésének kérdései, Gyógyszerészet, 141-150 (2014)

2. Hornyák, L; Nagy, Zs; Ilku, L; Tálos, Zs; Endrei, D;
Ágoston, I; Csákvári, T; Danku, N; Répásy, B; Boncz, I. Price competition and reimbursement of biosimilar granulocyte-colony stimulating factor in Hungary. Expert Rev Pharmacoecon Outcomes Res. 19(6), 725-731. (2019) https://doi.org/10.1080/14737167.201 9.1582334

3. Konangi S, Raviteja MN, Gupta N. Comparison Of Global Regulatory Approvals For Biosimilar Products. Int J PharmTech Res. 2013;5(3): 924-935.

4. https://www.ema.europa.eu/medicines/field_ ema_web_categories\%253Aname_field/Human/ ema_group_types / ema_medicine / field_ema_ med_status / authorised36 / ema_medicine_types / field_ema_med_biosimilar / Search_api_aggregation_ema_medicine_types / field_ema_med_biosimilar biohasonló gyógyszerek a speciális, biotechnológiailag elóállított gyógyszerek szabadalmának lejárta után forgalomba kerülő követő molekulák.

5. Hornyak, L., Nagy, Zs., Talos, Zs., Endrei, D., Agoston, I., Csakvari, T., Boncz, I. A biohasonló gyógyszerek árversenyének tapasztalatai Magyarországon. Acta Pharm Hung. 2014;84(2): 83-87.

6. Az Európai Parlament és a Tanács irányelve (2001. november 6.) az emberi felhasználásra szánt gyógyszerek közösségi kódexéről (2001/83/EK).

7. Az Európai Parlament és a Tanács 726/2004/EK rendelete (2004. március 31.) az emberi, illetve állatgyógyászati felhasználásra szánt gyógyszerek engedélyezésére és felügyeletére vonatkozó közösségi eljárá-sok meghatározásáról és az Európai Gyógyszerügynökség létrehozásáról.

8. 52/2005. (XI. 18.) EüM rendelet az emberi alkalmazásra kerülő gyógyszerek forgalomba hozataláról.

9. Az Európai Parlament és a Tanács 1394/2007/EK rendelete (2007. november 13.) a fejlett terápiás gyógy-szerkészítményekről, valamint a 2001/83/EK irányelv és a 726/2004/EK rendelet módosításáról.

10. Az Európai Parlament és a Tanács 2010/84/EU irányelve (2010. december 15.) az emberi felhasználásra szánt gyógyszerek közösségi kódexéről szóló 2001/83/ EK európai parlamenti és tanácsi irányelvnek a farmakovigilancia tekintetében történő módosításáról.

11. Az Európai Parlament és a Tanács 1235/2010/ EU. rendelete (2010. december 15.) az emberi, illetve állat-gyógyászati felhasználásra szánt gyógyszerek engedélyezésére és felügyeletére vonatkozó közösségi eljárások meghatározásáról és az Európai Gyógyszerügynökség létrehozásáról szóló 726/2004/EK rendeletnek és a fejlett terápiás gyógyszerkészítményekről szóló 1394/2007/EK rendeletnek az emberi felhasználásra szánt gyógyszerekkel összefüggésben követendő farmakovigilancia tekintetében történő módosításáról.

12. 15/2012. (VIII. 22.) EMMI rendelet az emberi alkalmazásra kerülő gyógyszerek farmakovigilanciájáról

13. 32/2004. (IV. 26.) ESzCsM rendelet a törzskönyvezett gyógyszerek és a különleges táplálkozási igényt 
kielégítő tápszerek társadalombiztosítási támogatásba való befogadásának szempontjairól és a befogadás vagy a támogatás megváltoztatásáról

14. Gulacsi, L., Boncz, I., Drummond, M.: Issues for countries considering introducing the "fourth hurdle": The case of Hungary. Int. J. Technol. Assess. Health Care. 20(3), 337-341 (2004). https://doi. org/10.1017/S0266462304001151

15. Boncz I, Evetovits T, Dózsa Cs, Sebestyén A, Gulácsi L, Ágoston I, Endrei D, Csákvári T, Getzen TE. The Hungarian Care Managing Organization Pilot Program. Value Health Reg Issues. 2015; 7:27-33. https:// doi.org/10.1016/j.vhri.2015.04.005

16. Boncz I, Kaló Z, Mohamed Ibrahim MIB, Greenberg D. Further steps in the development of pharmacoeconomics, outcomes research, and health technology assessment in Central and Eastern Europe, Western Asia, and Africa. Value Health Reg Issues. 2013; 2(2): 169-170. https://doi.org/10.1016/j.vhri.2013.07.007

17. Boncz, I., Nagy, J., Sebestyen, A., Korosi, L.: Financing of health care services in Hungary. Eur. J. Health Econ. 5(3), 252-258 (2004). https://doi.org/10.1007/ s10198-004-0228-3

18. Boncz, I., Dozsa, C., Kalo, Z., Nagy, L., Borcsek, B., Brandtmuller, A., Betlehem, J., Sebestyen, A., Gulacsi, L.: Development of health economics in Hungary between 1990-2006. Eur. J. Health Econ. 7(S1), 4-6 (2006). https://doi.org/10.1007/s10198-006-0364-Z

19. Boncz I, Sebestyen A. Financial deficits in the health services of the UK and Hungary. Lancet. 2006; 368(9539):917-918. https://doi.org/10.1016/S01406736(06)69369-0

20. Boncz I, Vajda R, Ágoston I, et al. Changes in the health status of the population of Central and Eastern European countries between 1990 and 2010. Eur J Health Econ. 2014 15; (S1):137-141 https://doi. org/10.1007/s10198-014-0602-8

21. Endrei D, Zemplényi A, Molics B, Ágoston I, Boncz I. The effect of performance-volume limit on the DRG based acute care hospital financing in Hungary. Health Policy. 2014; 115(2-3):152-156. https://doi. org/10.1016/j.healthpol.2013.12.005

22. Buzás Zs. [Allow biosimilar products on the European Medicines Agency for the system]. [Medical Training Review]. 2012;19(10): 73-79. Hungarian

23. Buzás, Zs.: Biohasonló készítmények engedélyezése az Európai Gyógyszerügynökség rendszerében. Orvostovábbképző Szemle. 19(10), 73-79 (2012)

24. Hirsch BR, Lyman GH. Biosimilars: are they ready for primetime in the United States? J. Natl Compr Canc Netw. 2011;9(8):934-942. https://doi. org/10.6004/jnccn.2011.0076

25. Covic A, Cannata-Andia J, Cancarini G, et al. Biosimilars and biopharmaceuticals: what the nephrologist needs to know - a position paper by the ERA-EDTA
Council. Nephrol Dial Transplant. 2008;23(12): 37313737 https://doi.org/10.1093/ndt/gfn519

26. Harsányi A, Csanádi M, Márky K, Vincziczki ÁZ, Kaló Z, Inotai A. Influence of biosimilar infliximab launch on the utilization pattern of biological medicines: the case of Hungary. Expert Rev Pharmacoecon Outcomes Res. 2020 Dec;20(6):653-659. doi: 10.1080/14737167.2019.1667232. Epub 2019 Sep 18. PMID: 31510811., https://doi.org/10.1080/14737167. 2019.1667232

27. Inotai A, Csanadi M, Petrova G, Dimitrova M, Bochenek T, Tesar T, York K, Fuksa L, Kostyuk A, Lorenzovici L, Omelyanovskiy V, Egyed K, Kalo Z. Patient Access, Unmet Medical Need, Expected Benefits, and Concerns Related to the Utilisation of Biosimilars in Eastern European Countries: A Survey of Experts. Biomed Res Int. 2018 Jan 10;2018:9597362. doi: 10.1155/2018/9597362. PMID: 29546072; PMCID: PMC5818964. https://doi.org/10.1155/2018/9597362

28. Kaló Z, Holtorf AP, Alfonso-Cristancho R, Shen J, Ágh T, Inotai A, Brixner D. Need for multicriteria evaluation of generic drug policies. Value Health. 2015 Mar;18(2):346-51. doi: 10.1016/j.jval.2014.12.012. Epub 2015 Feb 11. PMID: 25773570. https://doi. org/10.1016/j.jval.2014.12.012

29. Inotai A, Kaló Z. How to solve financing gap to ensure patient access to patented pharmaceuticals in CEE countries? - the good, the bad, and the ugly ways. Expert Rev Pharmacoecon Outcomes Res. 2019 Dec;19(6):627-632. doi:10.1080/14737167.2019.1702524. Epub 2019 Dec 10. PMID: 31810392, https://doi.org/10. 1080/14737167.2019.1702524

30. Sun D, Andayani TM, Altyar A, MacDonald K, Abraham I. Potential cost savings from chemotherapy-induced febrile neutropenia with biosimilar filgrastim and expanded access to targeted antineoplastic treatment across the European union g5 countries: a simulation study. Clin Ther. 2015;37(4):842-57 https://doi.org/10.1016/j.clinthera.2015.01.011

31. Gulácsi L, Brodszky V, Baji P, et al. The rituximab biosimilar CT-P10 in rheumatology and cancer: a budget impact analysis in 28 European Countries. Adv Ther. 2017;34(5):1128-1144. https://doi. org/10.1007/s12325-017-0522-y

32. Kim J, An Hong J, Kudrin A. 5 year budget impact analysis of CT-P13 (infliximab) for the treatment of Crohn's disease in UK, Italy and France. J Crohns Colitis. 2015;9(Suppl 1):S144. https://doi.org/10.1093/ ecco-jcc/jju027.254

33. Grewal S, Ramsey S, Balu S, et al. Cost-savings for biosimilars in the United States: a theoretical framework and budget impact case study application using filgrastim. Expert Rev Pharma coecon Outcomes Res. 2018;18(4):447-454. https://doi.org/10.1080/1473 7167.2018 .1476142 
